\title{
Toxicity of leadership and its impact on employees: Exploring the dynamics of leadership in an academic setting
}

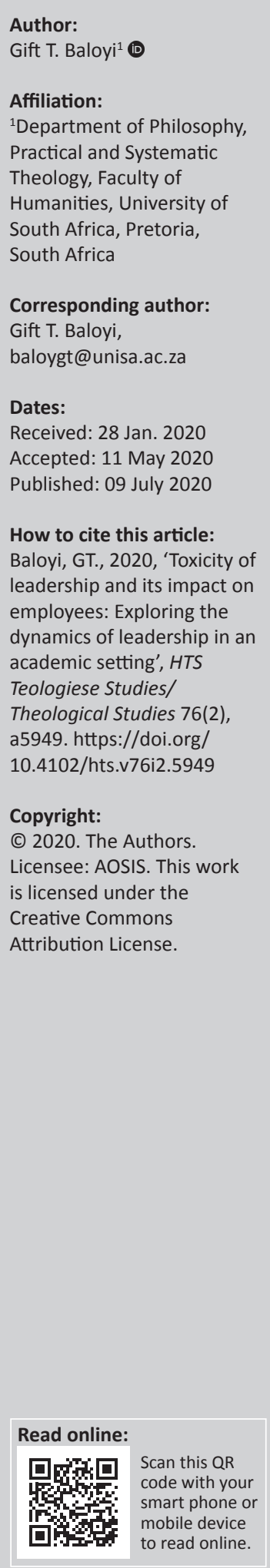

Constructive leaders highlight elements of motivation to employees to grow in order to achieve goals for their institutions or departments. They do this either through understanding the significance of ethical leadership or servant leadership. However, people who work under toxic environments often have little or no choice but drop their energy levels and be completely demoralised because of the toxicity at their workplace. This includes stories of leaders who ridicule their employees in public, force employees to undergo physical and psychological pains, and promote divisiveness between colleagues. As the article focuses on leadership, and toxic leadership that is destructive not only for the workplace but also for human relationship, it argues for a need of ethical leadership which creates a dynamic relationship and trust between a leader and those led. The article concludes by stating that there is a relationship between ethical leadership and employee performance, and that this is very important for academic institutions.

Contribution: Although the article reflects on the notion of leadership and its toxicity in an academic environment, the implications of the outcome are multidisciplinary, as ethical leadership is necessary in all human institutions (religion, politics, academia, corporate and social institutions or organisations).

Keywords: Destructive behaviour; Ethical leadership; Job satisfaction; Leadership; Toxic leadership.

\section{Introduction}

This article discusses the concept of leadership in an academic environment. Leadership has been a focal point of scholarly research for decades across the globe. The existence of leadership is as old as human civilisation itself. It is, therefore, one of the most essential components to have for the functioning of all institutions and organisations or departments. Although leadership is a broad concept without a standard definition, it is not about negativity and destruction.

Whilst numerous scholars (e.g. Herbst \& Conradie 2011:1-14; Kelidbari, Fadaei \& Ebrahimi 2016:463-470; eds. Samier \& Schmidt 2010) have dealt with traits, behaviours and styles that are associated with successful leadership, few have attempted to understand the nature and consequences of dysfunctional leadership (Schmidt 2008:1). In one way or another, most people have experienced bad leadership from different walks of life. There are various places where one could observe or experience bad leadership such as church leadership, place of employment or within political organisations etc.

This investigation focuses mainly on toxic leadership in institutions of higher learning within the context of South Africa. The article intends to use Herbst and Mukhola's (2018:183-193) empirical research findings on 'female leaders' experience of toxic leadership in higher education institutions in South Africa', as the basis of arguments put in this article. Although Herbs and Mukhola's research focus was on female leaders, the results of the study do give an indication or confirmation of the existence of toxicity in higher institutions and this is what is crucial for this article.

\section{The concept of leadership}

Leadership is one of the most vital aspects of life, which gives any organisation or institution in the world a competitive advantage. Leadership is said to be a process by which a leader inspires others within an organisation to achieve an organisation's set goals in a cohesive way. Its existence

Note: Special collection entitled Christian Leadership, sub-edited by Wessel Bentley (UNISA). 
is as old as human civilisation (Asrar-ul-Haq \& Anwar 2018:179) and has been observed in various institutions such as politics, religion, corporate and social. Whilst leadership is acknowledged to be as old as human civilisation, research shows that it is also one of the least understood traits, especially by those who occupy positions of leadership without necessary skills (see Amanchukwu et al. 2015:6). Leadership is about qualities that recognise other people's qualities whilst bringing out the best in them.

According to Amin, Tatlah and Islam (2018:161), leadership means to 'inspire many people for functioning as a body' or component. It is also defined as a tool to '...enhancing human potential' (Bijur 2000:167) and '...creating the environment within which things can be accomplished' (Matei \& VazquezBurguete 2012:206). Almaki et al. (2016:226) understand leadership as a '...means to influence others in order to complete a particular task...'. Whilst definitions of leadership may vary, the general sentiment remains the same: Leaders are those people who know how to achieve goals and inspire others along the way (Almaki et al. 2016). However, the substantial qualities of leadership, as indicated above, are generally visible in a leader who is trustworthy, ethical, experienced, knowledgeable, visionary and has a warm demeanour. These become fundamental principles for the effectiveness of leadership in an organisation.

Whilst this author agrees with other scholars that '... leadership doesn't have a one-size-fits-all definition...' (Almaki et al. 2016:226), it is important to mention that its meaning should give influence and inspiration to work towards group goals, not through coercion but through personal motivation' (Sart 2014:77). In other words, the complexity of the notion does not take away the fact that 'leadership lies in the ability to create a vision, motivation, and enthusiasm' (Stănciulescu \& Beldiman 2019:57). Its definition is also reliant on the type of institution or organisation it is defined for. Defining leadership from a religious or political point of view will surely differ from how a military institution understands and defines it. In the context of an academic environment, leadership could mean, amongst others, to excel in teaching, 'enhances the university's research mission and advances its position as a leading source of innovation' (Sart 2014:82; cf. Anjum et al. 2018:1-10). Such leadership should be able to lead, drive and influence transformation.

\section{Background of the study}

In their empirical study, Herbst and Mukhola (2018:183-193) were interested in the experiences of 'female leaders of toxic leadership by means of the Schmidt toxic leadership scale to observe the frequency of particular toxic leadership behaviour'. Their data were collected from a group of female leaders $(N=82)$ employed at 18 different higher education institutions in South Africa. Of the 82 participants, 48 responded to the survey. In their study, there was no identity or biographical data revealed, apart from the job levels of the participants. Of the 48 participants, 2 (4.17\%) were members of executive management committee, $3(6.25 \%)$ were executive deans, $6(12.5 \%)$ were heads of academic departments, $16(33.33 \%)$ were heads of support departments, $11(22.92 \%)$ were at non-management position (other) and 10 (20.83\%) were lecturers.

For the purpose of their research, '...the survey was designed to measure the following five dimensions of toxic leadership: self-promotion; abusive supervision; unpredictability; narcissism; and authoritarian leadership'. The high rank mean value for each of these five dimensions indicates that the majority of the participants either agree (5) or strongly agree (6) that their line manager demonstrated the 30 toxic leadership behaviours measured by the instrument (Herbst \& Mukhola 2018:187). The study findings do confirm that toxic leadership is a prevalent phenomenon in many South African universities. In terms of this empirical evidence, the two dimensions with the highest rank mean values are narcissism and selfpromotion. This is alarming because Schmidt's (2008) definition of narcissism includes lack of skill of developing empathy, ethical principles and underestimating others' abilities.

\section{Problematising toxicity at the workplace}

In an institution with leadership, there lies an assumption that people who undertake such leadership positions possess goodwill and intent for peers, employees and their institutions. It is further assumed that constructive leaders do highlight elements of motivation for employees to achieve goals and inspirations to do more than they thought was possible (eds. Samier \& Schmidt 2010:126). These assumptions speak hypothetically on the grounds that every leader in their position has the interest of advancing and growing their institutional agendas, which also empowers everyone in it. Furthermore, these assumptions are born out of the fact that leadership comes with responsibilities to drive innovation, development and encourage employees to improve their performance.

The assumption is, however, not necessarily what happens in practice. In this regard, there is enough empirical evidence in the context of South African higher education (Herbst \& Conradie 2011:1-14; Herbst \& Mukhola 2018:183-193; Mafini 2014; Ngcamu 2015:208-216), which acknowledges the existence of toxicity in academic space. In the context of an academic environment, where the production of knowledge is paramount, it becomes difficult if not impossible to work and give birth to new ideas under leadership that is toxic. This has negative consequences or outcomes on both employees and the institution at large. Bad leadership has the capacity to destroy collegiality and team atmosphere, and demoralises and, in the end, destroys skills that are necessary for productivity and growth of an institution. It also destroys people's cognitive psychology, that is, the ability to deal effectively with the mind and the way information is processed. 


\section{Exploring toxic leadership and the tactics of operation}

The notion, 'toxic leader' was never in use until its first appearance in Whicker (1996). The notion is associated with dark leadership which encompasses qualities such as 'destructive' (eds. Samier \& Schmidt 2010:125), 'abusive and tyrannical' (Pelletier 2010:374), 'narcissist' (Maccoby 2000:68-78) and 'aversive' (Bligh et al. 2007:528-557) style of leadership. Both 'toxic leadership' and 'dark leadership' are at times used interchangeably to describe the same challenges or phenomena in leadership. In the end, these concepts refer to leaders who engage in gravely destructive behaviours and exhibit dysfunctional personal qualities, inflicting severe physical and psychological damage to those being led and undermine the interest of the organisation. Such toxic leaders possess a 'deep-seated but well-disguised sense of personal inadequacy, selfish values, and cleverness at concealing deceit' (Whicker 1996:12).

In dealing with the etymology of the notion 'toxic' from the ancient Greek in terms of what it means, Frater (2014:374) states that "the word toxon means "bow," as well as "the arrows shot from the bow," and really just archery in general'. However, the notion was later revised and from toxon came the word 'toxicus', which mean 'poison for use on arrows' (Frater 2014:374), and later translated to Latin 'toxicus', and French 'toxique'. From this understanding, one finds common features between 'toxicus' (poisonous) on the arrows of the bow and leaders who inflict physical and psychological harm on the people they lead. These 'toxicus' qualities carry doses of poison with capacity to destroy either quickly or slowly depending on the nature or makeup of the target.

Toxic leadership breeds 'multidimensional construct that includes elements of abusive supervision along with narcissism, authoritarianism, self-promotion, and unpredictability' (Reed 2004:71) that are as dangerous as a dose of poison in a human body. This is also supported by Lipman-Blumen (2005:1), who argues that toxic leadership is '...a process in which leaders, by dint of their destructive behavior and/or dysfunctional personal characteristics, inflict serious and enduring harm on their followers, their organizations, and non-followers, alike'. Whilst a 'toxicus' arrow on a bow may kill instantly, toxic leadership destroys both psychologically and physically, leaving a person mentally paralysed. Toxic leadership may not kill instantly like an arrow shot from the bow, but it has the capacity to kill in the long run. It achieves its toxicity through systemic 'violent managerial practices...' (Cotter 2001:187) and exhibiting '... dysfunctional personal qualities inflicting severe physical and psychological damage to followers...' (Herbst \& Mukhola 2018:185; cf. Mehta \& Maheshwari 2014:19).

However, one acknowledges that there is no perfect leadership and that all types of leadership may have more elements of abusiveness than others depending on the situation; nevertheless, the dose of 'toxicus' in a particular leadership being displayed is the cause of the collapse of collegiality or team spirit and demoralised attitudes towards performance. It is also important to note that whilst people may regard toxic leaders as poisonous for a working environment, some regard them as their heroes. Even when such leaders are characterised by, amongst other qualities, self-glorification, pettiness, abusiveness and interpersonal malice (Whicker 1996:66), they are still regarded with respect by some of their followers. Lipman-Blumen (2005:376) point out that they also '...exhibit destructive behaviors that work to decay their followers' morale, motivation, and self-esteem, although there is considerable overlap in conceptualizations of toxic, tyrannical, unethical, and destructive leadership'.

Because of their inadequacies, they employ certain tactics in order to operate (Pelletier 2010:375-376). This is indicative of the fact that such 'toxic leaders are fundamentally characterized by three dysfunctional qualities: deep-seated inadequacy, selfish values, and deceptiveness' (Whicker 1996:53). In addition, because of lack of good qualities and the necessary abilities to cope with and carry out their tasks, they resort to this type of leadership in order to scare and frustrate their colleagues, at times to a point of the colleagues quitting their jobs. This does not only result in the destruction of collegiality spirit, harming the institution and the people, it is a destruction of basic human sense of trust. Such leaders have no sense of comprehending the fact that basic human sense of trust is 'critical for working relationships, effective leadership, the university as site of democracy [and space for knowledge production], and [a breeding of] a healthy society' (eds. Samier \& Schmidt 2010:134).

Toxic leaders often create what Lewis (1944, cited in Kretzschmar 2019:19-20) calls '...inner ring...' which is always in total support of anything the leader does. This includes violation of institutional policies, destruction of human relations and ultimately collapsing the division or department they have been entrusted with. The role of the 'inner ring' is to strengthen the muscles of a toxic leader. Drawing from Lewis, Kretzschmar (2019:20) argues that '...no "big man" can become powerful or remain in power, without the support of an "inner ring." It is a mutually corrupting association'. This 'inner ring' also shows a total disregard of principles of ethics and morality. According to Mehta and Maheshwari's (2014:18-24) argument, employees who agree to be a part of the circle or 'inner ring' are rewarded for agreeing with the leader but could be reprimanded for challenging their authority. Some of the employees in the circle may agree not because of wisdom or reliability of the leader but because of fear of victimisation.

This style of leadership has today established itself as 'silent killers' (Walton 2007:19) of both humans and institutions. Subordinates who are not in the circle or the leader's support structure are dismissed or dealt with when they question the leader's ways and decisions. This attitude occurs despite the fact and knowledge that independency of mind ought to take the centre stage at an institution of 
higher learning. As Klein (2010) correctly states in Samier and Schmidt (eds. 2010) that such:

[T] oxic leadership penetrates into the fabric of university life and society, alters it, and hereby defines the university not as a site of democracy and freedom, but rather as a work-place marked by constraint, torture, and injustice. (p. 134)

Although their toxicity may not necessarily display toxic behaviours in all situations, they are able to manipulate a situation to appear as though they are good leaders. The point is nonetheless that they are not trustworthy or even truthful leaders. Notwithstanding that toxic leaders have different methods of displaying their skills and characters, but what they have in common is '...deep-seated but welldisguised sense of personal inadequacy, selfish values and cleverness at concealing deceit' (Herbst \& Mukhola 2018:185).

Samier and Schmidt (eds. 2010:128) point out that 'targets within a university setting typically excel well above departmental or college norms and expectations tend to be highly productive scholars...' However, in some instances, targets may not necessarily be in the category as described above but may be because of their association or rather guilty by association. As observed by Samier and Schmidt (eds. 2010:128-129), once toxic leaders have identified their targets, they work to control and intimidate them with implicit threats with the desired outcome of influencing the target to a weak position.

\section{Impact of toxic leadership}

Toxic leadership has a huge negative impact on individual as well as institution. In the academic space, it has devastating impact on academics, teaching and learning and the institution at large. It has the capacity to erode the purpose of the existence of institutions of higher learning in societies. Herbst and Mukhola's (2018:183-193) research findings do confirm that the existence of toxicity of leadership in South Africa's higher learning institutions is prevalent with negative outcomes. These findings are indicative of the fact that toxic leaders in higher academic institutions do not have any sense of trust, understanding of academic administration and basic human relations. It is not clear whether this suggests lack of comprehension and purpose for being in academic leadership in line with the purpose for the existence of academic institutions in society. There is a sense of deeprooted pathology which allows such toxicity to occur without any slightest feeling of pain towards others.

Toxicity in any academic space has the potential to inhibit proper teaching and learning and suppress knowledge production by academics (cf. Giroux 2015:5-16). Toxicity has no space for helping colleagues aiming at setting the highest standards of research and teaching in order to be competitive with other global institutions. It is nonetheless capable of devising means to frustrate academics to a point of psychological distress. This type of leadership indirectly denies the whole idea of intellectual space where research breaks new grounds and enables both researchers and the institution to lead in research. A space that is not conducive for producing knowledge will be equally not conducive for training young minds to move and grow the economy of their country.

For a better functioning of higher learning institutions, employees require to be free from toxicity. In other words, toxic leadership '...is associated with the decreased employee performance, increased level of psychological distress and low level of job satisfaction and commitment' (Hussein et al. 2018:32). In agreement with Hussein et al. (2018), the functioning of human body in its totality is vital for interaction, especially in the academic space, on issues relating to research, teaching and learning vigorously. This shows how bad is the toxic leadership together with its associates such as '...destructive leadership, abusive supervision, petty tyranny, narcissistic leadership, and authoritarian leadership...' (Burns 2017:45).

Further, physical and psychological implications include '... loss of concentration, panic attacks...' (eds. Samier \& Schmidt 2010:133) and '...sleep difficulties' (Hansen et al. 2014:285), especially on those who are targets of toxic leaders. In such environments, there is a high probability of post-traumatic stress disorder (PTSD) in employees because of repeated psychological and emotional abuse. Depending on the level of stress from a toxic workspace, there is a probability of '... broad range of effects on brain function and structure, as well as on neuropsychological components of memory' (Bremner 2006:455). It is essential to indicate that the human brain is a significant contributor to the holistic functioning of a human body. Therefore, it becomes impossible for a person to function fully and vigorously in an environment that obstructs proper functioning of the brain. This leads to a question such as, how does teaching and learning (as a way of imparting knowledge) and research take place effectively when a significant part of the body (the brain) is paralysed by stress?

This contributes to the weakening of values placed by hardworking employees in departments and/or institutions. Furthermore, it results in some employees resigning or moving to other institutions of higher learning in anticipation and hope for peace and freedom of mind. It also diminishes the production strength of department and 'may result in teaching and learning ineffectiveness and/or lack of scholarly productivity' (eds. Samier \& Schmidt 2010:134). No matter how much strong are one's cognitive systems, a toxic work environment has the capacity to damage one's capabilities and functioning to the core. Whether or not such leaders are aware of the grave consequences of their toxicity for individuals and institutions at large, the results of their bad leadership are always at their disposal and visible.

\section{Traits of a toxic leader}

The complexity of the nature of toxic leaders makes it necessary to understand the reasons why they behave in a 
toxic manner. The article has explored toxic leadership, its tactics of operation and its impact on the people being led. In order to change harmful leadership styles, it is important to have knowledge of why it exists. Zimbardo (2008) reminds us about the importance of understanding the environmental factors and why toxic leadership occurs and the irrevocable damage caused by it. There are many reasons as to why toxic leaders behave the way they do in a working environment; however, some reasons stand as leading factors above the rest. Toxic leaders are characterised by certain behavioural patterns, which according to Pelletier (2010:882) include, amongst others, lack of integrity and honesty, lack of moral philosophy, lack of confidence and incompetence (cf. LipmanBlumen 2005).

Other researchers (see Lubit 2004:1-7; Padilla et al. 2007: 176-194) have identified a toxic leader as a narcissist who displays an illegitimate sense of entitlement, need for administration, lack of empathy and projection of negative traits onto others (cf. Samier \& Atkins 2009). They point out that what is consistent about narcissistic leaders in universities is that they are 'likely to violate policies, principles of administrative law, and natural justice' (Samier \& Atkins 2009:219). In other words, these are the most problematic leaders who often lead to self-serving and abuse of power. At times, they refuse to be accountable for their words and actions and demand unquestioning obedience.

\section{Pelletier (2010, cited in Burns 2017) found that:}

[T]oxic leaders are also skilled at fostering an 'us/them' dichotomy for the purpose of enhancing cronyism ('us'); in promoting this dichotomy, leaders maliciously set constituents against one another by identifying scapegoats and inciting their followers to castigate them; toxic leaders erode unit cohesion and deflate esprit de corps; and that abusive leadership is related positively to turnover intentions and psychological distress, and related negatively to affective and continuance commitment, job and life satisfaction. (p. 46)

At some point, they do not see any need to report back to colleagues or even defend the interest of the department or their portfolios simply because they see themselves as better leaders connected with higher structures than their subdivisions. In addition, Leet (2011:111-112) states that they '...live with the unrealistic expectations that everyone around them is there to provide service to them explicitly...', failing which results in unspeakable psychological harm on the individual. By psychological harm, the present author refers to an individual's sense of self-esteem and mental health which is affected by humiliations rendered by toxic leader. This, in general, has implications for both institution or organisation and employees.

\section{A need for ethical leadership}

A toxic leader is characterised by (amongst other qualities) abuse, lack of collegiality, deep-seated inadequacy, selfish values and deceptiveness, which display a deep lack of understanding of basic principles of ethics. Ethics are fundamental as they deal with questions of morality beyond personal level. Ethics are considered vital not only for the growth of every institution or organisation but also for the promotion of teamwork amongst colleagues. It is important for leaders to have qualities of high moral principles. According to Ahmad, Gao and Hail (2017:10), 'Leadership without ethics and integrity can be harmful both for the organizational stakeholders and society'.

Perhaps, before dealing with ethical leadership theory (as a proposed model for academic leadership), it is imperative to deal briefly with its definition. According to Rich (2013):

$[E]$ thics is a systematic approach to understanding, analyzing, and distinguishing matters of right and wrong, good and bad, and admirable and deplorable as they relate to the well-being of and the relationship among sentient beings. (p. 4)

It is also understood as 'principles of conduct governing an individual or group' (Merriam-Webster 2012). Cheteni and Shindika (2017:5) have cited Brown, Trevino and Harrison (2005), who defines ethics as a '...demonstration of normatively appropriate conduct through personal actions and interpersonal relationships, and the promotion of such conduct to followers through two-way communication, reinforcement, and decision-making'. Whilst these definitions may vary, the core message or general sentiment remains the same, that is, possessing moral principles.

Although Rich (2013) gives a clear definition of what 'ethics' is in general, Brown et al. (2005:120) define ethical leadership as the 'demonstration of normatively appropriate conduct through personal actions and interpersonal relationships, and the promotion of such conduct to followers through twoway communication, reinforcement, and decision making'. This has the capacity to create strong collegial spirit characterised by '...integrity, honesty, and trustworthy' (Treviño, Brown \& Hartman 2003:21). Moreover, to create a caring and beneficial environment for both workers and organisation, ethical leadership must encompass qualities of 'moral person' and 'moral manager' (Ahmad et al. 2017:12), engage in righteous acts and avoid harmful acts to others, and their actions must be based on altruistic motives rather than on self-centred motifs (Kanungo 2001:257-265).

Any leadership, irrespective of institution or organisation, needs basic understanding of ethics as defined above. This helps in cultivating an attitude of moral obligation and personal responsibility in any level of work and leadership. This is very important especially for leaders as their behaviour influences individuals being led to cultivate and work by high moral principles. This is necessary for the growth and success of organisation. Ethics also provides an opportunity for the leader and followers to work as a strong unit. This is more relevant in a country such as South Africa where ethical leadership is not visible clearly (cf. Kretzschmar 2019:17-27). Challenges of corruption, nepotism and bad leadership are deeply established in many institutions and organisations. Institutions of higher 
learning, departments and other organisations are not excluded from these challenges. Therefore, this emphasises the need for sound leadership, which acknowledges that transparency is inextricably based on ethical principles.

Academic administrations in South Africa, through institutional policies, require a moral person and a moral manager to use their managerial powers to encourage and promote ethical standards and behaviour. Furthermore, ethical leadership helps to eliminate the unnecessary violation of policies and principles of administrative laws which contribute to the success of a leader and the credibility of institution. Thus, ethical leadership becomes an administration characterised by empathy and caring for the utmost functioning of institution/organisation. In such an environment, employees are highly encouraged and motivated to work and reach their full potential and make their departments successful. Principles of ethical leadership also acknowledge that basic human sense of trust is 'critical for working relationships...' (eds. Samier \& Schmidt 2010:134), and where trust and relationships are built authentically, there is hope for holistic growth.

Reciprocal confidence develops through good relationships between leaders and followers, allowing the leader and followers to take department or institution to a higher level. This is fundamental, especially in an academic environment where the growth of an institution is depended on its type of leadership. The moment toxic leadership is given a space to crawl in, it then decides the time for the collapse of department or institution. In a working environment where ethics are highly promoted and respected, there is no space for toxicity, which breeds physical and psychological harm to employees and decreases productivity and personal growth.

Ethical leadership is an important aspect of authentic transformation. However, where ethics are not attached to any form of leadership, there is little interest for genuine transformation. Whilst ethical leadership specifically looks at the interests of the institution by applying its policies equally to every employee, toxicity has a propensity of creating a strong circle of friendship which supports anything wrong carried out by the leader, including destruction of human trust, policies and collegiality. Therefore, authentic transformation cannot emerge in such toxic environments because toxicity is not ethical in nature and is far from bringing authentic transformation and growth. Instead, toxicity plays alongside pseudo-transformation, which is characterised by self-interest, lack of morality and is poweroriented. The danger of toxic style of leadership is that it carries many destructive qualities that do not care about the well-being of others, their growth and that of institution.

\section{Ethical leadership and employee performance}

Kelidbari et al. (2016:464) states that ' $[i] n$ every organization the staff performance is regarded as one of the most important concepts'. Any leader in their position should strive to improve and enhance the institution's or departmental employees' performance by appearing more ethical in their way of leadership. Such leaders have a potential to encourage their employees to improve their performance and raise their morale and job satisfaction. Here, job satisfaction refers to a feeling of happiness a person attains from their job, without necessarily focusing on remuneration. This article concurs with Yates (2014:1112) that ethical leadership is linked with employee's performance and job satisfaction.

Employee performance is typically determined by the type of relationship that exists between employees and their leader and how they interact with each other. Walumbwa et al. (2011:205) points out that '... the more frequently employees interact with their immediate supervisors, the more likely the relationship will be stronger'. In ethical leadership, a leader who is morally and ethically upright has an understanding that the success of institution or department is determined by the high-quality relationship between them and those led by them. Therefore, it is very critical for direct-line managers to improve good working relationship with their employees and be committed to ethical values, as it adds to the characteristics of a highly efficient leader.

Kelidbari et al. (2016:469) maintain that ethical leaders strive to act in the best interests of their employees as well as department; this explains and confirms commitment and trust of employees. When employees observe that leaders act in their best interests and are caring, the result is enhanced quality and production. This in itself is taking employees in confidence and thereby creating trust between a leader and their employees. This high level of confidence leads to emotional connections and mutual support, which in the end confirms growth of both individual employee and institution) and transformation in institution.

\section{Conclusion}

Toxic leadership has greater effects on the growth of an institution and its employees. It affects job satisfaction of employees and reduces the quality of work and renders institution into disarray. For effective transformation and achievement to take place in institutions of higher learning, there is a strong need for ethical leadership. Morality, ethical behaviour and fairness are the pinnacle of ethical leadership to positively influence and motivate others (Hartog 2015:409-434) to achieve great things and become ethical in their daily lives. People who aspire to be in leadership positions require training on matters of ethics and morals in leadership. It is imperative for such people to acquire skills that enable them to lead ethically, effectively, efficiently and innovatively. It is necessary that toxic leaders are provided with thorough training in order to understand the purpose of ethical leadership, especially in an academic setting. It is nonetheless known that generally toxic leaders won't participate willingly in any training session designed to change their leadership style to align with the interests of 
the organisation and its constituents or stakeholders. Another reason could be that they do not know that they are toxic leaders. However, whether they have knowledge or not about their toxicity, such training should still be provided. They should understand the purpose of such training sessions aimed at helping them understand their working environment in order to grow.

\section{Acknowledgements Competing interests}

The author declares that he has no financial or personal relationships that may have inappropriately influenced him in writing this article.

\section{Author's contributions}

G.T.B. is the sole author of this research article.

\section{Ethical considerations}

This article followed all ethical standards for a research without direct contact with human or animal subjects.

\section{Funding information}

This research received no specific grant from any funding agency in the public, commercial or not-for-profit sectors.

\section{Data availability statement}

Data sharing is not applicable to this article as no new data were created or analysed in this study.

\section{Disclaimer}

The views and opinions expressed in this article are those of the author and do not necessarily reflect the official policy or position of any affiliated agency of the author.

\section{References}

Ahmad, I., Gao, Y. \& Hail, S.M., 2017, 'A review of ethical leadership and other ethics related leadership theories', European Scientific Journal 13(29), 10-23. https:// related leadership theories', European
doi.org/10.19044/esj.2017.v13n29p10

Almaki, S.H., Silong, A.D., Idris, K. \& Wahat, N.W., 2016, 'Understanding of the meaning of leadership from the perspective of Muslim women academic leaders', Journal of Educational and Social Research 6(2), 225-236. https://doi. org/10.5901/jesr.2016.v6n2p225

Amanchukwu, R.N., Stanley, G.J. \& Ololube, N.P., 2015, 'A review of leadership theories, principles and styles and their relevance to educational management', Management 5(1), 6-14.

Amin, M., Tatlah, J. \& Islam, M., 2018, 'Leadership styles of the campus principals and divisional directors in a public university of Pakistan', Bulletin of Education and Research 40(1), 155-181.

Anjum, A., Ming, X., Siddiqi, A.F. \& Rasool, S.F., 2018, 'An empirical study analyzing job productivity in toxic workplace environments', International Journal of Environmental Research and Public Health 15(5), 1035. https://doi.org/10.3390/ ijerph15051035

Asrar-ul-Haq, M. \& Anwar, S., 2018, 'The many faces of leadership: Proposing research agenda through a review of literature', Future Business Journal 4(2), 179-188.

Bijur, P., 2000, 'The energy of leadership', in W. Dauphinais, G. Means \& C. Price (eds.), Wisdom of the CEO, pp. 167-174, Wiley, New York, NY.

Bligh, M.C., Kohles, J.C., Pearce, C.L., Justin, J.E. \& Stovall, J.F., 2007, 'When the romance is over: Follower perspectives of aversive leadership', Applied Psychology 56(4), 528-557. https://doi.org/10.1111/j.1464-0597.2007.00303.x

Bremner, J.D., 2006, 'Traumatic stress: Effects on the brain', Dialogues in Clinical Neuroscience 8(4), 445-461.
Brown, M., Trevino, L. \& Harrison, D.A., 2005, 'Ethical leadership: A social learning perspective for construct development and testing', Organizational Behavior and Human Decision Processes 97(2), 117-134. https://doi.org/10.1016/j.obhdp. 2005.03.002

Burns, W.A, 2017, 'A descriptive literature review of harmful leadership styles: Definitions, commonalities, measurements, negative impacts, and ways to improve these harmful leadership styles', Creighton Journal of Interdisciplinary improve these harmful leadership styles', Creighton Journal
Leadership 3(1), 33-52. https://doi.org/10.17062/cjil.v3i1.53

Cheteni, P. \& Shindika, E.S., 2017, 'Ethical leadership in South Africa and Botswana', Brazilian Administration Review 14(2), 1-19.

Cotter, J., 2001, 'Sexual harassment as/and (self) invention: Class, sexuality, pedagogy, and (creative) writing', in M. Zavarzadeh, T.L. Ebert \& D. Morton (eds.), Marxism, queer theory, gender, pp. 155-216, Red Factory, Syracuse, NY.

Frater, J., 2014, Listverse.com's epic book of mind-boggling lists: Unbelievable facts and astounding trivia on movies, music, crime, celebrities, history, and more, Ulysses Press, Brooklyn, NY.

Giroux, H., 2015, 'Neoliberalism's war against higher education and the role of public intellectuals', Límite. Revista Interdisciplinaria de Filosofía y Psicología 10(34), 5-16.

Hansen, A.M., Hogh, A., Garde, A.H. \& Persson, R., 2014, 'Workplace bullying and sleep difficulties: A 2-year follow-up study', International Archives of Occupational and Environmental Health 87(3), 285-294. https://doi.org/10.1007/s00420-0130860-2

Hartog, D.N.D., 2015, 'Ethical leadership', Annual Review of Organizational Psychology and Organizational Behavior 2(1), 409-434. https://doi.org/10.1146/annurevorgpsych-032414-111237

Herbst, T.H.H. \& Conradie, P.D.P., 2011, 'Leadership effectiveness in higher education: Managerial self-perceptions versus perceptions of others', South African Journal of Industrial Psychology 37(1), 1-14. https://doi.org/10.4102/ sajip.v37i1.867

Herbst, T.H.H. \& Mukhola, M.S., 2018, 'Female leaders' experience of toxic leadership in higher education institutions in South Africa', in N. Delener \& C. Scheikert (eds.) Global business and technology association: 20th international conference, GBATA proceedings, Bangkok, Thailand, July 3-7, 2018, pp. 183-193.

Hussein, G.A.S., Wang, H., Hesham, M.A.H. \& Madina, K., 2018, 'Dark leadership impact on psychological well-being and work-family conflict: Implications for project success of Bahrain companies', Journal of International Business Research and Marketing 3(3), 32-39. https://doi.org/10.18775/jibrm.1849-8558.2015. 33.3003

Kanungo, R.N., 2001, 'Ethical values of transactional and transformational leaders', Canadian Journal of Administrative Sciences/Revue Canadienne des Sciences de l'Administration 18(4), 257-265. https://doi.org/10.1111/j.1936-4490.2001. tb00261.x

Kelidbari, H.R.R., Fadaei, M. \& Ebrahimi, P., 2016, 'The role of ethical leadership on employee performance in Guilan University of Medical Sciences', Procedia Social and Behavioral Sciences 230(15), 463-470. https://doi.org/10.1016/j. sbspro.2016.09.058

Klein, S.R., 2010, 'Toxic leadership and the erosion of trust in higher education', in E.A. Samier \& M. Schmidt (eds.), Trust and betrayal in educational administration and leadership, pp. 125-140, Routledge, London.

Kretzschmar, L., 2019, 'An ethical analysis of "big man" and "inner ring" leadership in South Africa: The example of Jacob Zuma and the resistance of Thuli Madonsela", in S. Jung, V. Kessler, L. Kretzschmar \& E. Meier (eds.), Metaphors for leading Leading by metaphors, pp. 17-27, V \& R Unipress, Göttingen.

Leet, E., 2011, 'The impact toxic or severe dysfunctional leadership has on the effectiveness of an organisation', PhD thesis, Murdoch University.

Lipman-Blumen, J., 2005, The allure of toxic leaders: Why we follow destructive bosses and corrupt politicians - and how we can survive them, Oxford University Press, Oxford.

Lubit, R., 2004, 'The tyranny of toxic managers: Applying emotional intelligence to deal with difficult personalities', Ivey Business Journal Online 68(4), 1-7.

Maccoby, M., 2000, 'Narcissistic leaders: The incredible pros, the inevitable cons', Harvard Business Review 78(1), 68-78.

Mafini, C., 2014, 'Tracking the employee satisfaction-life satisfaction binary: The case of South African academics', SA Journal of Industrial Psychology/ SA Tydskrif vir Bedryfsielkunde 40(2), 1-11. https://doi.org/10.4102/sajip. v40i2.1181

Matei, L. \& Vazquez-Burguete, J.L., 2012, Public and non-profit marketing: Proceedings, vol. 33, Permanent Study Group, Bucharest.

Mehta, S. \& Maheshwari, G.C., 2014, 'Toxic leadership: Tracing the destructive trail', International Journal of Management 5(10), 18-24.

Merriam-Webster Dictionary, 2012, Ethic, viewed 26 January 2020, from https:// www.merriam-webster.com/dictionary/ethics.

Ngcamu, B.S., 2015, 'Leadership and transformation in a South African university', Problems and Perspectives in Management 13(1), 208-216.

Padilla, A., Hogan, R. \& Kaiser, R. B., 2007, 'The toxic triangle: Destructive leaders, susceptible followers and conducive environments', The Leadership Quarterly 18(3), 176-194.

Pelletier, K.L., 2010, 'Leader toxicity: An empirical investigation of toxic behavior and rhetoric', Leadership 6(4) 373-389. https://doi.org/10.1177/1742715010 379308

Reed, G.E., 2004, 'Toxic leadership', Military Review 84(July-August), 67-71. 
Rich, K.L., 2013, 'Introduction to ethics', in J.B. Butts \& K.L. Rich (eds.), Nursing ethics - Across the curriculum and into practice, pp. 3-30, 3rd edn., Jones \& ethics - Across the curricul
Bartlett, Burlingham, MA

Samier, E.A. \& Atkins, T., 2009, 'Psychopathy in educational leadership: The problem of narcissists in positions of power', in E.A. Samier \& M. Schmidt (eds.), Emotional dimensions of educational administration and leadership, pp. 212-223, Routledge, London.

Samier, E.A. \& Schmidt, M. (eds.), 2010, Trust and betrayal in educational administration and leadership, Routledge, London.

Sart, G., 2014, 'The new leadership model of university management for innovation and entrepreneurship', Eurasian Journal of Educational Research 57, 73-90. https://doi.org/10.14689/ejer.2014.57.6

Schmidt, A.A., 2008, Development and validation of the toxic leadership scale, MA dissertation, University of Maryland.

Stănciulescu, R. \& Beldiman, E., 2019, 'The issue of leadership styles in the military organization', Land Forces Academy Review 1(93), 54-60. https://doi.org/10.2478/ raft-2019-0006
Treviño, L.K., Brown, M.E. \& Hartman, L.P., 2003, 'A qualitative investigation of perceived executive ethical leadership: Perceptions from inside and outside the executive suite', Human Relations 56(1), 5-37. https://doi.org/10.1177/001872 6703056001448

Walton, M., 2007, 'Leadership toxicity - An inevitable affliction of organisations?', Organisations \& People 14(1), 19-27.

Walumbwa, F.O., Mayer, D.M., Wang, P., Wang, H., Workman, K. \& Christensen, A.L., 2011, 'Linking ethical leadership to employee performance: The roles of leadermember exchange, self-efficacy, and organizational identification', Organizational Behavior and Human Decision Process 115(2), 204-213. https://doi.org/10.1016/j. obhdp.2010.11.002

Whicker, M.L., 1996, Toxic leaders: When organizations go bad, Praeger, Westport, CT.

Yates, L.A., 2014, 'Exploring the relationship of ethical leadership with job satisfaction, organizational commitment, and organizational citizenship behavior', The Journa of Values-Based Leadership 7(1), 1-15.

Zimbardo, P., 2008, The Lucifer effect: Understanding how good people turn evil, Random House, New York, NY. 